\title{
Influence of State Banks on Economic Growth: A Cross-Country Analysis
}

\author{
Valentyna Onyshchenko
}

$\mathrm{PhD}$, Head of Cherkasy Oblast Administration of JSC "State Savings Bank of Ukraine" (Oschadbank), Ukraine

\section{Brian Xing Chen}

MS, Researcher of Xferl Research, Canada

\begin{abstract}
The authors systematize the economic-mathematical models, as well as the results of empirical studies of authoritative international analytical agencies and financial institutions, in which the influence of state capital in the banking system on the development of national economies was formalized on different countries in different periods. The analysis showed that such studies often give some completely opposite results. The reason for these authors is that the sample of countries in these models is formed mainly taking into account differences in the scale of state participation and levels of economic development of countries. This approach is erroneous because it does not take into account the specifics of the construction of the financial sector in these countries and the functions performed by the state banks.
\end{abstract}

Keywords: state bank, economic growth, economic and mathematical models.

JEL Classification: O42, P43, P51.

(C) The Authors, 2017. This article is published with open access at ARMG Publishing.

\section{Introduction}

Most economic studies of the late twentieth century are devoted to research problems of state banks as from a commercial point of view, and in the context of a possible imbalance in the allocation of public financial resources, rising politicization of the banking sector, reducing the quality of financial intermediation more. As a result of the global financial crisis of 2008-2009, many countries of the world (including Ukraine) were forced to nationalize problematic private banks, which increased the share of state property in banking systems (for example, in countries with world leaders - from 7.3\% in 2007 to 10.8\% in 2009). The above-mentioned circumstances gave a new impetus to the revival of scientific discussions on the functions of banks with state participation in the economy, the mechanisms for their functioning and place in the financial system.

Fundamentals study the influence of banks with state participation in the development of countries' economies inherent in scientific research works such as John. Bart T. Beck, G. Huizinha E. Demirguc-Kunt, S. Zervos, L. Zinhales A. Andrews, J. Caprio, T. Kerner, R. King, R. Levin, N. Loyaz, M. Martínez Peria, F. Lopez-deSilanes, R. La Porta, A. Schleifer, I. Schnebel et al. The synthesis of scientific literature on the studied issues allows us to argue that there is no single point of view on the impact (positive or negative) of banks with state participation on economic growth and the development of national economies.

\section{Methods and findings}

In the process of solving the research tasks put forward by the authors in the article, the following methods of analysis, synthesis and logical generalization were used; comparative analysis - in analyzing the functioning of banking systems of countries of the world with different levels of state participation in banks' capital; correlation and regression analysis - in assessing the impact of state banks on the level of socio-economic development of the country.

Here are the arguments and the results of the research carried out to confirm the negative impact of state capital in the banking system on economic growth and the development of the national economy:

- Increasing the presence of the state in the financial sector leads to a reduction in the degree of availability of credit resources for business entities (this conclusion is confirmed by studies (La Porta, 1999), in which this degree of accessibility is determined on the basis of calculation of that share of loans to private companies 
that are not included in the twenty largest enterprises, as well as using the general analytical indicator of the availability of credit resources);

- an increase in the state's presence in the banking system leads to a decrease in the efficiency of its functioning (this conclusion is confirmed by studies (La Porta, 1999), which established the relationship between the volume of state capital in the banking system and indicators such as: the ratio of indirect costs and total assets, between interest rates on deposits and loans);

- the increase in the proportion of banks with public participation in the banking system reduces its financial stability and stability (this conclusion is confirmed by studies (La Porta, 1999), which established the relationship between the volume of state capital in the banking system and indicators such as: inflation, an integrated indicator of financial stability banks, also the share of troubled assets, etc.);

- an increase in the share of banks with state participation in the banking system reduces the growth rate of productivity of the financial sector adjusted for the corresponding increase of capital (this conclusion is confirmed by researches (Beck,Crivelli, 2005; Beck. Levine , 2000; King, 1993; La Porta, Lôpez-de-Silanes, 2002; Rajan, 1998);

- significant state involvement in the banking sector correlates with a low level of financial intermediation (this conclusion is confirmed by studies (Beck,Crivelli, 2005; Beck. Levine , 2000; King, 1993; La Porta, Lôpez-de-Silanes, 2002; Rajan, 1998);

- an increase in the share of state participation in the banking system leads to imbalances in the allocation of financial resources of the state. This is due to the possibility of combining state ownership of banks with the government's desire to finance inefficient but politically significant projects, which are often devoid of positive value for the society of states (this conclusion is confirmed by researches Levy Yeyati, Micco, 2004);

- the efficiency of state banks is much lower compared to commercial private banks, which in turn leads to a slowdown in economic growth of the country, which is especially relevant for countries with economies in transition and underdeveloped countries (this conclusion is confirmed by researches Levy Yeyati, Micco, 2004);

- the existence of banks with state participation enables the state to control the investment decisions of financial institutions, based solely on political motives (this conclusion is confirmed by studies (Beck,Crivelli, 2005; Beck, Levine, 2000; King, 1993; La Porta, Lôpez-de-Silanes, 2002; Rajan, 1998);

- state banks may be required (either in the form of direct directives or indirectly, through appropriate regulatory influence) to finance inefficient state-owned enterprises, to provide financing to borrowers in certain regions / sectors of the economy under non-market conditions, to pursue a credit policy based on political motives and priorities.

- The arguments and the results of the research carried out to confirm the positive influence of the state capital in the banking system on economic growth and development of the national economy:

- increasing the presence of the state in its financial sector provides stable rates of development of financial intermediation, namely: development of lending by state banks of private enterprises and development of new types of financial and economic cooperation - subsidization of commercial banks, standardized contracts, more efficient lending to sectors of the national economy, construction systems of additional guarantees for banks subject to the development of long-term lending, etc. (This conclusion is confirmed by research (Demirguc-Kunt, 2000; Demirguc-Kunt, Maksimovic, 1998; Gershenkron, 1962));

- the presence of a state in the banking system generally increases its financial stability, as financial and credit institutions dependent on borrowed funds in the form of financial resources deposits may face a significant outflow problem with the insignificant role of the state in the financial system, which, on a macroeconomic scale, may lead to the deterioration of financial stability and stability of both banks and the entire banking system. In addition, the state is a certain stabilizing factor that in some way protects commercial banks from the influence of external negative factors (this conclusion is confirmed by researches Levy Yeyati, Micco, 2004);

- an increase in the share of banks with state participation in the banking system reduces the imperfection of the financial markets of the country (this conclusion is confirmed by researches Levy Yeyati, Micco 2004, Lewis, 1955; Myrdal, 1971); 
- publicly-owned banks provide investment in financial resources in socially meaningful but ineffective projects in terms of profit. This opens up new opportunities for the state to overcome the institutional inefficiency of private capital markets, stimulate aggregate supply in the market, which in the long run stimulates the pace of economic growth of the state. (this conclusion is confirmed by researches Levy Yeyati, Micco, 2004, Lewis, 1955; Myrdal, 1971);

- state capital in the banking system stimulates the development of the financial sector as a whole (this conclusion is confirmed by researches Levy Yeyati, Micco, 2004, Myrdal, 1971);

- a significant factor influencing the state's presence in the banking system is the possibility of financing projects at those stages of economic cycles in which commercial banks can not or do not want to do so. Most clearly this occurs during an economic recession in the country, or if such projects involve significant external risks or if the financial and economic potential of individual regions of the state is not within the scope of the interests of private banking capital (this conclusion is confirmed by studies Levy Yeyati, Micco, 2004);

- significant participation of the state in the banking system has a positive effect on the efficiency of the banking business (this conclusion is confirmed by researches (Levy Yeyati, Micco, 2004, Myrdal, 1971));

- an increase in the share of the state in capital or assets of the banking system has a positive effect on the expansion of production and employment of the population (this conclusion is confirmed by researches (Levy Yeyati, Micco, 2004, Myrdal, 1971);

- significant participation of the state in the banking system contributes to leveling the levels of economic development of potentially unprofitable sectors of the economy (this conclusion is confirmed by researches) (Levy Yeyati, Micco, 2004, Myrdal, 1971);

- state-owned banks, using the reputation of more reliable and stable institutions, can attract significant amounts of financial resources, thereby improving the quality of financial intermediation;

- an increase in the share of banks with state participation in the banking system makes it less vulnerable to the expansion of foreign capital;

- the scale of state participation in the banking system has a positive impact on the gross income per capita, as well as investment activity (gross investment in fixed assets);

- Public-sector banks play an important role in stabilizing loans during the economic cycle and during periods of financial instability, which allows for the use of an increase in state participation in the banking system as a temporary short-term countercyclical instrument. World Bank experts have proved that a $1 \%$ increase in the GDP growth rate is caused by a $2.0 \%$ increase in lending rates for private banks, and only $0.6 \%$ by state banks. This means that the purpose of state banks is to stabilize loans during the economic cycle, and not simply maximize profits (this conclusion is confirmed by research, the results of which are illustrated in Table 1).

Analysis of the data presented in Table. 1, it is possible to conclude that the process of lending to business entities by state banks is stable during the business cycle in cases where the bank is in a country with a high level of efficiency index of public administration. The quality of public administration is a key aspect in ensuring the implementation of the function of stabilizing general lending by state banks during the economic cycle. In developing countries, loans of state banks are less pro-cyclical character than loans of private banks. Loans of state banks in developed countries were also less procyclical than private bank loans, we can even conclude their anti-cyclical nature.

Thus, state-owned banks perform better the function of stabilizing overall credit activity in developed countries, since the ability of state-owned banks to stabilize loans is most in demand during the period of the financial crisis. Research shows that public banks are increasing their loans is during banking crises, as opposed to the reduction of credit activity of private banks.

Greater stability of state banks' loans during the economic cycle implies more stable financing. During the economic boom state banks require less additional funds for further lending. The analysis showed that state banks are increasing non-depozitory sources of funding only during a relatively small period of economic boom. The low dependence of state-owned banks on non-deposit financing in the period of economic upsets partly explains the fact that they maintain lending levels during recessions. 
The analysis of the relationship between the level of non-performing state bank loans and the level of lending activity suggests that state banks show a lower level of problem loans compared to private banks during periods of economic growth, and vice versa. It smoothes the capital base of state-owned banks, as well as their ability to provide new loans, compared to private banks (Myrdal 1971).

Among the issues that researchers are investigating within the framework of the functioning of state banks is also an analysis of their impact on the country's economic development, with the level of public participation and degree of protection of property rights are the most significant problems in this context. However, despite the significant amount of research, scientists could not clearly determine the effect of state banks on economic development.

The generalization of the above arguments about the positive or negative impact of the state's participation in the banking system on economic growth suggests that studies conducted by reputable and well-known specialists in this area often give absolutely opposite results. Thus, it is logical to assume that the problem is not in the form of research or incorrect economic logic, which is the basis for interpreting these results.

In our opinion, the reason for such diametrically opposed conclusions about the impact of banks with state participation on economic growth and the development of national economies is the failure to consider the mathematical models of the specifics of the countries under study. Therefore, none of the above arguments can be fair to any country. We believe that the effects of state presence in the banking system is not uniform for all sample countries not to suggest the magnitude and even the direction of this action clearly demonstrated.

Thus, the size of the state's participation in the financial sector of the country is a determining factor in the impact on its development, and a certain list of specific characteristics of the financial sector itself. The effect of increasing the fate of the state's participation in the banking system of the country on the indicators of its economic development (in particular, on GDP growth per capita) depends strongly on the level of development of the banking system itself, in particular, on the quality of functioning of financial institutions, the bank's banking system.

In countries with underdeveloped financial sector and low quality of functioning of political institutions, the negative impact was rather significant, but it gradually declined with the development of the financial sector. Therefore, under other conditions, with the financial sector reaching a certain level of its development and in the absence of the possibility of political forces through state banks to ensure the fulfillment of their private interests, the effect of increasing the state presence was absent or even positive.

In general, agreeing with the thesis that the impact of state-owned bank capital on the development of the national economy will be different for countries with different levels of financial sector development, we believe that, besides this, this influence also significantly depends on the functions assigned to state-owned banks.

On this basis, we propose to adequately test the hypothesis about the influence of the state's participation in the banking system on the development of the national economy to formulate a sample of countries not according to the criterion of different amounts of state participation in banks' capital, but according to the criterion of different functional load of banks with state participation in the banking system and the national the economy as a whole. Thus, the fundamental difference between the approach that will be set out in this section of the dissertation research, from the other, which has become widespread in the scientific literature, is the orientation towards the target benchmarks in the activity of the state-controlled banks.

Based on the difference in the construction of a corporate governance system in public and private banks, they have a diversified and multidirectional impact on the development of the national economy. The main functional task of a commercial bank is to maximize its profit, and thus, the creation and implementation of an effective system for collecting, systematizing and analyzing information about potential clients, as well as diversifying activities, target groups and markets is one of the priorities of the management of such a bank. In the case where the bank's owner is a state, the list of its functions is somewhat different, with the main task of such financial intermediaries being financing projects that for certain reasons can not be financed by private investment capital, but the effect of their implementation for society as a whole should be positive.

On the basis of summarizing world experience of functioning of banks with state participation within national economies and banking systems around the world we offer are two models of operation of such banks by their functional load in the economic system and targets: 
1. Model 1. It is envisaged that state-owned banks operate on a general basis with other commercial banks, carry out the same list of operations, but in some cases are oriented to servicing certain sectors of the economy or economic activities. Within this model, such banks are formed as a result of the nationalization of some troubled banks as a means of preserving the financial stability of the banking system in times of crisis, due to historically established traditions and political ideology, etc..

2. Model 2. Banks with state participation occupy a completely separate place in the banking system, perform exclusively the functions of financial agents of the government in the implementation of national socioeconomic development programs. The list of operations and target benchmarks for such banks and ordinary commercial banks is very different in this case. Within this model, banks with public participation are formed specifically for specific tasks of implementing the state economic development strategy, not because of historical traditions or current conditions of post-crisis stabilization.

The generalization of the world experience in the functioning of banks with state participation made it possible to assert that in virtually all countries where the state has a share in the capital of banks, they are created and operate according to the model.

1. China, where this model has been operating since the early 1990s, is the only country in which state-owned banks are based on model 2 in its pure form. Partly on the way to the formation of model 2 are now Russia and India, but as the system of banks with state participation in these countries is now actively reformed, the only illustrative example of this model will be China.

Consider the impact of banks with state participation in economic growth in the countries where the system of banks modeled on one.

Most studies conducted by countries that form their banking system according to model 1 show the negative impact of state participation in the banking system of the country on economic growth and indicators of financial stability of the banking system.

Thus, in particular, according to a study conducted on the example of 65 countries of the world, it is proved that the depth and scale of the effects of the crisis in general are positively correlated with the degree of state participation in the banking system. The research also confirms the negative impact of the state's participation in the banking sector on the characteristics of the country's financial and economic development. That is, countries with a significant level of state participation in the banking system, as a rule, have a lower level of development of the banking intermediation system, as well as lower rates of development of the non-financial sector of the economy and the stock market.

It is advisable in this direction to consider the study on the impact of the increase of the share of state property in the financial sector on the example of 92 countries with different levels of economic development in the system of indicators proposed by T. Beck, N. Loyazi and R. Levit. According to the results of this study, it was found that an increase in the state's presence in the banking system is slowly hampering economic development (an increase in the share of the state in the banking system by $10 \%$ leads to a decline in the rate of economic development by $0.23 \%$ ). Summarized results of this study are illustrated in tables 2 and 3 .

Table 2. Results of the analysis of the influence of the state participation in the banking system on the development of the economies of the countries where the system of banks with public participation is constructed according to model 1

\begin{tabular}{|c|c|c|c|c|c|c|c|}
\hline \multirow{3}{*}{$\begin{array}{l}\text { Dependent } \\
\text { variables: }\end{array}$} & \multicolumn{7}{|c|}{ Explanatory Variables } \\
\hline & GB70 & $\begin{array}{l}\text { Recorded } \\
\text { GDP per } \\
\text { capita in } \\
1960\end{array}$ & $\begin{array}{c}\text { The initial volume } \\
\text { of loans to } \\
\text { households to GDP }\end{array}$ & $\begin{array}{l}\text { Initial amount } \\
\text { of liquid credit } \\
\text { obligations to } \\
\text { GDP }\end{array}$ & $\begin{array}{l}\text { Initial amount of } \\
\text { commercial } \\
\text { bank assets to } \\
\text { total assets }\end{array}$ & $\begin{array}{c}\text { Initial } \\
\text { capitalization of } \\
\text { the stock } \\
\text { exchange to } \\
\text { GDP }\end{array}$ & $\begin{array}{c}\text { The } \\
\text { adjusted } \\
\text { value R2 }\end{array}$ \\
\hline & \multicolumn{7}{|c|}{ Part 1: Financial development } \\
\hline $\begin{array}{l}\text { Growth of loans to } \\
\text { households to GDP }\end{array}$ & $\begin{array}{l}-0.0394^{\mathrm{a}} \\
(0.0107)\end{array}$ & $\begin{array}{l}-0.0006 \\
(0.0043)\end{array}$ & $-0.058^{\mathrm{a}}(0.0187)$ & & & & $\begin{array}{l}0.2111 \\
{[82]}\end{array}$ \\
\hline $\begin{array}{l}\text { Growth of liquid liabil- } \\
\text { ities to GDP }\end{array}$ & $\begin{array}{l}-0.0138^{c} \\
(0.0079)\end{array}$ & $\begin{array}{l}-0.0015 \\
(0.0028)\end{array}$ & & $\begin{array}{l}-0470^{\mathrm{a}} \\
(0.0147)\end{array}$ & & & $\begin{array}{l}0.2475 \\
{[82]}\end{array}$ \\
\hline $\begin{array}{l}\text { Growth of assets of } \\
\text { commercial banks to } \\
\text { total assets }\end{array}$ & $\begin{array}{l}-0.0050 \\
(0.0048)\end{array}$ & $\begin{array}{l}0.0041^{\mathrm{c}} \\
(0.0022)\end{array}$ & & & $-0.0741^{\mathrm{a}}(0.0178)$ & & $\begin{array}{l}0.4456 \\
{[82]}\end{array}$ \\
\hline
\end{tabular}


Table 2. Results of the analysis of the influence of the state participation in the banking system on the development of the economies of the countries where the system of banks with public participation is constructed according to model 1

\begin{tabular}{|c|c|c|c|c|c|c|c|}
\hline \multirow[b]{2}{*}{$\begin{array}{l}\text { Dependent } \\
\text { variables: }\end{array}$} & \multicolumn{7}{|c|}{ Explanatory Variables } \\
\hline & GB70 & $\begin{array}{l}\text { Recorded } \\
\text { GDP per } \\
\text { capita in } \\
1960\end{array}$ & $\begin{array}{l}\text { The initial volume } \\
\text { of loans to } \\
\text { households to GDP }\end{array}$ & $\begin{array}{c}\text { Initial amount } \\
\text { of liquid credit } \\
\text { obligations to } \\
\text { GDP }\end{array}$ & $\begin{array}{l}\text { Initial amount of } \\
\text { commercial } \\
\text { bank assets to } \\
\text { total assets }\end{array}$ & \begin{tabular}{|c|} 
Initial \\
capitalization of \\
the stock \\
exchange to \\
GDP \\
\end{tabular} & $\begin{array}{l}\text { The } \\
\text { adjusted } \\
\text { value R2 }\end{array}$ \\
\hline $\begin{array}{l}\text { Growth of stock market } \\
\text { capitalization to GDP }\end{array}$ & $\begin{array}{c}0.0071 \\
(0.0341) \\
\end{array}$ & $\begin{array}{l}-0.0338^{\mathrm{b}} \\
(0.0148) \\
\end{array}$ & & & & \begin{tabular}{|l|}
$-0.0760^{\mathrm{a}}$ \\
$(0.0254)$ \\
\end{tabular} & $\begin{array}{l}0.2880 \\
{[47]} \\
\end{array}$ \\
\hline \multirow[t]{2}{*}{$\begin{array}{l}\text { Changes in stock mar- } \\
\text { ket capitalization to } \\
\text { GDP }\end{array}$} & $\begin{array}{l}-0.5306^{\mathrm{a}} \\
(0.1620)\end{array}$ & $\begin{array}{l}-0.0305 \\
(0.0411)\end{array}$ & & & & $-0.1000(0.3382)$ & $\begin{array}{l}0.1910 \\
{[67]}\end{array}$ \\
\hline & \multicolumn{7}{|c|}{ Part 2: Access to credit resources } \\
\hline $\begin{array}{l}\text { Private requirements-re- } \\
\text { quirements of firms not } \\
\text { included in the } 20 \text { largest } \\
\text { to GDP }\end{array}$ & $\begin{array}{l}-0.3153^{\mathrm{c}} \\
(0.1749)\end{array}$ & $\begin{array}{l}-0.0231 \\
(0.0595)\end{array}$ & $0.6118^{\mathrm{c}}(0.3121)$ & & & & $\begin{array}{l}0.3551 \\
{[32]}\end{array}$ \\
\hline \multirow[t]{2}{*}{ Availability of loans } & $\begin{array}{l}-0.5787^{\mathrm{b}} \\
(0.2629) \\
\end{array}$ & $\begin{array}{c}0.5152^{\mathrm{a}} \\
(0.0914) \\
\end{array}$ & $0.2772(0.2714)$ & & & & $\begin{array}{l}0.4810 \\
{[54]} \\
\end{array}$ \\
\hline & \multicolumn{7}{|c|}{ Part 3: Efficiency of the banking system } \\
\hline $\begin{array}{l}\text { Variable cost of banks } \\
\text { to total assets }\end{array}$ & $\begin{array}{c}0.0232^{\mathrm{a}} \\
(0.0067)\end{array}$ & $\begin{array}{l}-0.0012 \\
(0.0026)\end{array}$ & $-0.0134(0.0107)$ & & & & $\begin{array}{l}0.1856 \\
{[79]}\end{array}$ \\
\hline \multirow[t]{2}{*}{ Effect of interest rate } & $\begin{array}{c}22.2802^{\mathrm{a}} \\
7.2241) \\
\end{array}$ & $\begin{array}{c}4.1503 \\
(4.1113) \\
\end{array}$ & $-27.6439^{\mathrm{c}}(14.4694)$ & & & & $\begin{array}{l}0.1539 \\
{[58]}\end{array}$ \\
\hline & \multicolumn{7}{|c|}{ Part 4: Financial Stability } \\
\hline $\begin{array}{l}\text { Financial stability of } \\
\text { banks }\end{array}$ & $\begin{array}{l}-1.2416^{\mathrm{b}} \\
(0.5205) \\
\end{array}$ & $\begin{array}{c}0.7522^{\mathrm{a}} \\
(0.1564) \\
\end{array}$ & $0.3818(0.4794)$ & & & & $\begin{array}{l}0.4387 \\
{[54]} \\
\end{array}$ \\
\hline \multirow[t]{2}{*}{ Inflation rate } & $\begin{array}{l}0.1198^{\mathrm{a}} \\
0.0363)\end{array}$ & $\begin{array}{c}0.0095 \\
(0.0146) \\
\end{array}$ & $-0.0719(0.0477)$ & & & & $\begin{array}{l}0.1537 \\
{[68]}\end{array}$ \\
\hline & \multicolumn{7}{|c|}{ Part 5: Capital Market } \\
\hline $\begin{array}{l}\text { Capitalization of the } \\
\text { stock market in } 1995\end{array}$ & $\begin{array}{l}-0.7411^{\mathrm{a}} \\
(0.2058) \\
\end{array}$ & $\begin{array}{c}0.0089 \\
(0.0422) \\
\end{array}$ & & & & & $\begin{array}{l}0.2570 \\
{[70]} \\
\end{array}$ \\
\hline $\begin{array}{l}\text { Capitalization of the } \\
\text { stock market in } 1995\end{array}$ & $\begin{array}{l}-0.5409^{\mathrm{a}} \\
(0.1762)\end{array}$ & $\begin{array}{l}-0.0343 \\
(0.0438)\end{array}$ & & & & $0.9011^{\mathrm{a}}(0.3404)$ & $\begin{array}{l}0.5036 \\
{[62]}\end{array}$ \\
\hline
\end{tabular}

Table 3 - Regression equations of dependence of economic growth indicators and state participation in the banking system for different countries of the world in which the system of state-owned banks is based on model 1

\begin{tabular}{|c|c|c|c|c|c|c|c|c|}
\hline \multirow[b]{2}{*}{$\begin{array}{l}\text { Dependent } \\
\text { variables }\end{array}$} & \multicolumn{8}{|c|}{ Explanatory Variables } \\
\hline & GB70 & $\begin{array}{c}\text { Registered } \\
\text { GDP } \\
\text { per capita }\end{array}$ & $\begin{array}{c}\text { The initial } \\
\text { volume of } \\
\text { loans to } \\
\text { households } \\
\text { to GDP }\end{array}$ & $\begin{array}{l}\text { Initial amount } \\
\text { of liquid credit } \\
\text { obligations to } \\
\text { GDP }\end{array}$ & $\begin{array}{c}\text { Initial volume } \\
\text { commercial } \\
\text { bank assets to } \\
\text { total assets }\end{array}$ & $\begin{array}{c}\text { Initial } \\
\text { capitalization of } \\
\text { the stock } \\
\text { exchange to } \\
\text { GDP }\end{array}$ & $\begin{array}{c}\text { Average } \\
\text { annual } \\
\text { values }\end{array}$ & $\begin{array}{c}\text { The } \\
\text { adjusted } \\
\text { value R2 }\end{array}$ \\
\hline $\begin{array}{l}\text { GDP per capita } \\
\text { in } 1960-1995 \text {. }\end{array}$ & $\begin{array}{l}-0.0235^{\mathrm{a}} \\
(0.0077)\end{array}$ & $\begin{array}{l}-0.0065^{\mathrm{b}} \\
(0.0032)\end{array}$ & & & & $\begin{array}{l}\text { Initial capitaliza- } \\
\text { tion of the stock } \\
\text { exchange to } \\
\text { GDP }\end{array}$ & & $\begin{array}{c}0.1240 \\
{[85]}\end{array}$ \\
\hline $\begin{array}{l}\text { GDP per capita } \\
\text { in } 1960-1995 \text {. }\end{array}$ & $\begin{array}{l}-0.0199^{a} \\
(0.0071)\end{array}$ & $\begin{array}{l}-0.0160^{\mathrm{a}} \\
(0.0033)\end{array}$ & & & & & $\begin{array}{c}0.0061^{\mathrm{a}} \\
(0.0013)\end{array}$ & $\begin{array}{c}0.3403 \\
{[85]}\end{array}$ \\
\hline $\begin{array}{l}\text { GDP per capita } \\
\text { in } 1960-1995 \text {. }\end{array}$ & $\begin{array}{l}-0.0171^{b} \\
(0.0072)\end{array}$ & $\begin{array}{l}-0.0175^{\mathrm{a}} \\
(0.0030)\end{array}$ & $\begin{array}{c}0.0302^{\mathrm{a}} \\
(0.0103)\end{array}$ & & & & $\begin{array}{c}0.0055^{\mathrm{a}} \\
(0.0012)\end{array}$ & $\begin{array}{c}0.4168 \\
{[82]}\end{array}$ \\
\hline $\begin{array}{l}\text { GDP per capita } \\
\text { in } 1960-1995 \text {. }\end{array}$ & $\begin{array}{l}-0.0152^{\mathrm{c}} \\
(0.0079)\end{array}$ & $\begin{array}{l}-0.0166^{\mathrm{a}} \\
(0.0032) \\
\end{array}$ & & $0.0198^{\mathrm{a}}(0.0086)$ & & & $\begin{array}{c}0.0057^{\mathrm{a}} \\
(0.0013) \\
\end{array}$ & $\begin{array}{c}0.3835 \\
{[82]} \\
\end{array}$ \\
\hline $\begin{array}{l}\text { GDP per capita } \\
\text { in } 1960-1995 \text {. }\end{array}$ & $\begin{array}{l}-0.0180^{b} \\
(0.0084) \\
\end{array}$ & $\begin{array}{l}-0.0160^{\mathrm{a}} \\
(0.0037) \\
\end{array}$ & & & $\begin{array}{c}0.0026 \\
(0.0136) \\
\end{array}$ & & $\begin{array}{c}0.0062^{\mathrm{a}} \\
(0.0014) \\
\end{array}$ & $\begin{array}{c}0.3216 \\
{[83]} \\
\end{array}$ \\
\hline $\begin{array}{l}\text { GDP per capita } \\
\text { in } 1960-1995 \text {. }\end{array}$ & $\begin{array}{l}-0.0160^{\mathrm{c}} \\
(0.0082) \\
\end{array}$ & $\begin{array}{l}-0.0134^{\mathrm{a}} \\
(0.0034) \\
\end{array}$ & & & & $0.0146^{\mathrm{b}}(0.0014)$ & $\begin{array}{c}0.0050^{\mathrm{a}} \\
(0.0014) \\
\end{array}$ & $\begin{array}{c}0.3028 \\
{[75]} \\
\end{array}$ \\
\hline $\begin{array}{l}\text { GDP per capita } \\
\text { in } 1960-1995 \text {. }\end{array}$ & $\begin{array}{l}-0.0140^{c} \\
(0.0083)\end{array}$ & $\begin{array}{l}-0.0151^{\mathrm{a}} \\
(0.0032)\end{array}$ & $\begin{array}{c}0.0263^{\mathrm{b}} \\
(0.0105)\end{array}$ & & & $0.0107(0.0084)$ & $\begin{array}{c}0.0047^{\mathrm{a}} \\
(0.0013)\end{array}$ & $\begin{array}{c}0.3671 \\
{[73]}\end{array}$ \\
\hline
\end{tabular}


$a$ - significance at the level of $1 \%$; b - significance at the level of $5 \%$; - significance at the level of $10 \%$. Standard errors are shown in brackets.

We should provide a thorough study on the BRIC countries, 2001-2009. As a result, it was concluded that there is no statistically significant influence of state presence on the indicators of depth and structural characteristics of national banking mediation. It is proved that state participation at the present stage of development of BRIC countries does not have a negative impact on the level of banking mediation and the main indicators of economic growth. The main results of this study are illustrated in Table. 4

At the same time, in all BRIC countries, the banking system is modeled on model 2 in its pure form. Thus, in particular, according to expert estimates, Indian state banks hold slightly less than $80 \%$ of the total loan portfolio of the whole banking system of the country. Although there is a slight tendency to reduce the share of the public sector in the country's financial system, it does not, according to experts, decline below 55-65\%.

Table 4. Summarized results of the study of the influence of the share of banks with state participation in the banking system of the country on the indicators of economic development of these countries

\begin{tabular}{|c|c|c|}
\hline \multirow[b]{2}{*}{ Dependent variable } & \multicolumn{2}{|c|}{$\begin{array}{c}\text { Study period } \\
\text { (country of study) }\end{array}$} \\
\hline & $\begin{array}{c}\text { 1995-2002 } \\
\text { (Brazil, China, } \\
\text { India, indonesia } \\
\text { Mexico, Pakistan) }\end{array}$ & $\begin{array}{l}\text { 2001-2009 (Brazil, } \\
\text { Russia, India, China) }\end{array}$ \\
\hline Assets / GDP & 0 & $\begin{array}{l}-0,097081 \\
{[0,019731]}\end{array}$ \\
\hline Loans / GDP & 0 & 0 \\
\hline Deposits / GDP & $\begin{array}{c}1,982113 \\
{[0,561883]}\end{array}$ & 0 \\
\hline Loans to the state sector / GDP & 0 & 0 \\
\hline Private sector loans / GDP & 0 & 0 \\
\hline Interest margin & 0 & 0 \\
\hline Consumer loans / Assets & $\begin{array}{c}1,108594 \\
{[0,288735]}\end{array}$ & - \\
\hline Reserves for loans / Assets & 0 & - \\
\hline Inactive loans / Assets & 0 & - \\
\hline Money Mass / Money base & 0 & - \\
\hline Deposits on demand / Term deposits & 0 & - \\
\hline Money / [Money + Quasi Money] & - & 0 \\
\hline
\end{tabular}

Notes: 0 - No statistically significant effect. [] - Standard error. * - With a 10\% significance level. «-» - no data.

Thus, the banking systems of Brazil, India and Russia are moving towards a Chinese format for the construction of the banking system, but this path is not yet complete. They have already moved away from the construction of a system of banks with state participation in model 1, but in its pure form, model 2 has not yet come closer. The main issue that they still have to deal with is the implementation of government programs to support the national economy through state-owned banks.

As far as China is concerned, it has been moving since 1979 to the modern organization of the banking system. During this period, a system of political banks was created (specialized banks issuing funds to support state economic policy), a system of state commercial banks (serving as a financial support to the reform process in China, gradually achieving these goals, these banks become more independent self-sustaining structures, administrative control over their activities is reduced), and commercial banks.

Currently, the banking system of China's dominant role played by the four major banks ( "Big Four"), owned by the state, they own more than $75 \%$ of banking system assets. According to research, the state controls more than $90 \%$ of the assets of the banking system.

China is the only country in the world where today's system of purely state-owned banks is based on model 2. At the same time, unfortunately, there is currently no solid research on this country separately and not of all BRIC countries that would formalize the impact of state capital in the banking system on the pace of economic development in a given country. Therefore, below we will conduct such an author's research.

Based on these data, we constructed regressive dependencies: 
- GDP per capita from assets of state-owned banks in China;

- the rate of GDP growth from assets of state-owned banks in China. As a control variable, in this case, the volume of export was used;

- share of exports in GDP from the indicator of the share of state-owned banks in the assets of the banking sector in China.

In summary, the results of research carried out by us demonstrated in the table 5 .

Table 5. Summarized results of author's study of the influence of state capital in the banking system of China on the pace of economic development (in brackets the standard error is given)

\begin{tabular}{|c|c|c|c|c|c|c|c|c|c|}
\hline \multirow[b]{3}{*}{$\begin{array}{l}\text { Inde-pendent } \\
\text { variables }\end{array}$} & \multicolumn{9}{|c|}{ Dependent variables } \\
\hline & \multicolumn{3}{|c|}{ GDP per capita } & \multicolumn{3}{|c|}{ GDP growth rate } & \multicolumn{3}{|c|}{ Export share in GDP } \\
\hline & $\begin{array}{l}\text { Coefficient } \\
\text { with } \\
\text { independent } \\
\text { variable }\end{array}$ & t-statistics & $\begin{array}{c}\text { Probability } \\
\text { of obtaining } \\
\text { a casual } \\
\text { result }\end{array}$ & $\begin{array}{l}\text { Coefficient } \\
\text { with } \\
\text { independent } \\
\text { variable }\end{array}$ & t-statistics & $\begin{array}{l}\text { The proba-bility } \\
\text { of getting a ran- } \\
\text { dom result }\end{array}$ & $\begin{array}{l}\text { Coeffi- } \\
\text { cient with } \\
\text { inde- } \\
\text { pendent } \\
\text { variable }\end{array}$ & t-statistics & $\begin{array}{l}\text { The proba- } \\
\text { bility of } \\
\text { getting a } \\
\text { random } \\
\text { result }\end{array}$ \\
\hline $\begin{array}{l}\text { Assets of state- } \\
\text { owned banks }\end{array}$ & $\begin{array}{c}8.002389 \\
(0.188248) \\
\end{array}$ & 42.50989 & 0.0000 & $\begin{array}{c}0.024521 \\
(0.008041) \\
\end{array}$ & 3.049358 & 0.0555 & & & \\
\hline $\begin{array}{l}\text { Export } \\
\text { volumes }\end{array}$ & & & & $\begin{array}{c}0.157011 \\
(0.056479) \\
\end{array}$ & 2.779994 & 0.0690 & & & \\
\hline $\begin{array}{l}\text { A set of assets } \\
\text { of state-owned } \\
\text { banks in the as- } \\
\text { sets of the } \\
\text { banking sys- } \\
\text { tem }\end{array}$ & & & & & & & $\begin{array}{c}0.316433 \\
(0.048994)\end{array}$ & 6.458596 & 0.0007 \\
\hline $\begin{array}{ll}\begin{array}{l}\text { FDI } \\
\text { inflows) }\end{array} & \text { (net } \\
\end{array}$ & & & & & & & $\begin{array}{c}3.827545 \\
(0.801593)\end{array}$ & 4.774925 & 0.0031 \\
\hline $\begin{array}{l}\text { Number of } \\
\text { observatios }\end{array}$ & & 8 & & & 5 & & & 8 & \\
\hline Study period & & $2008-2015$ & & & $2009-2015$ & & & $2008-2015$ & \\
\hline $\begin{array}{l}\text { Deter- } \\
\text { mination } \\
\text { coefficient }\end{array}$ & & 0.973839 & & & 0.914785 & & & 0.808449 & \\
\hline $\begin{array}{l}\text { Adjusted } \\
\text { determi-nation } \\
\text { factor }\end{array}$ & & 0.973839 & & & 0.886380 & & & 0.776524 & \\
\hline $\begin{array}{l}\text { Standard error } \\
\text { regression }\end{array}$ & & 187.0868 & & & 0.604203 & & & 2.174436 & \\
\hline $\begin{array}{l}\text { Amount of } \\
\text { residual } \\
\text { squares }\end{array}$ & & 245010.3 & & & 1.095184 & & & 28.36904 & \\
\hline $\begin{array}{l}\text { Akaike } \\
\text { Criterion }\end{array}$ & & 13.41749 & & & 2.119362 & & & 4.603734 & \\
\hline $\begin{array}{l}\text { Schwarz } \\
\text { criterion }\end{array}$ & & 13.42742 & & & 1.963137 & & & 4.623594 & \\
\hline $\begin{array}{l}\text { Darwin- } \\
\text { Watson } \\
\text { Criterion }\end{array}$ & & 1.403434 & & & 1.343619 & & & 2.907218 & \\
\hline
\end{tabular}

Analyzing data, shown in Table 5, we will focus mainly on the coefficient sign with independent variables. For all three regression dependences we construct, the coefficients are positive. indicating a positive effect of the assets of state banks on the indicators of economic growth in China: GDP per capita. the GDP growth rate and the share of exports in GDP. The regression dependences we have constructed are adequate. and conclusions. made on their basis - quite fair. because:

- t-statistics for each coefficient - more critical;

- The probability of error is very low: for the I and III equations - about $0 \%$. for the II equation - 5-6\%. This means. that probability of accidental reception of dependence is extremely small;

- The adjusted determination coefficient is very high for all three equations $(97 \%, 89 \%$ and $78 \%$ respectively). which testifies to that. that the change of the dependent variable (per capita GDP, the GDP 
growth rate and the share of exports in GDP) is precisely due to the change in the independent variable (assets of state-owned banks).

So the construction of a system of banks with state participation, according to model 2, contributes to economic growth (which proves the dependence of GDP per capita on assets of state-owned banks). an increase in its pace (as evidenced by the dependence of the GDP growth rate on the assets of state banks) and the growth of export-oriented country (as evidenced by the dependence of the share of exports in GDP from assets of state-owned banks).

\section{Conclusions}

In the study of the influence of state capital in the banking system on economic growth, a sample of countries should be formed not in the light of differences in the scale of state participation and levels of economic development of countries. but based on the specifics of building a financial sector in these countries and functions. which are executed by state banks. Functioning of state-owned banks on the example of China. In the study of the influence of state capital in the banking system on economic growth, a sample of countries should be formed not in the light of differences in the scale of state participation and levels of economic development of countries. but based on the specifics of building a financial sector in these countries and functions. which are executed by state banks. Functioning of state-owned banks on the example of China. When they occupy a completely separate place in the banking system. perform exclusively functions of financial agents of the government and differ from private banks according to the list of operations and target benchmarks. can provide a positive impact on the country's economic development.

The analysis showed. that such studies often give absolutely opposite results. The reason for this is seen by the authors that the sample of countries in these models is formed mainly taking into account differences in the level of state participation and levels of economic development of countries. The error of this approach is proved because it does not take into account the specifics of building a financial sector in these countries and functions which are executed by state banks. It is proposed to group countries in conducting such studies. proceeding from that. according to what principle state banks function in them:

1) State-owned banks operate on a common basis with other banks. carry out the same list of operations. but in some cases, focused on servicing specific sectors of the economy;

2) State banks occupy a completely separate place in the banking system. carry out exclusively functions of financial agents of the government in the implementation of national programs of socio-economic ro-tion. the list of operations and target benchmarks for such banks and private banks is significantly different.

In most countries, where the state has a stake in the capital of banks, they are created and operate on the first principle. The authors relied on the results of research by IMF and World Bank experts. which proved the negative influence of state banks on economic growth and the level of development of national economies in these countries.

\section{References}

1. Andrews, A. M. (2005). State-Owned Banks. Stability. Privatization. and Growth: Practical Policy Decisions in a World Without Empirical Proof. IMF Working Paper № WP/05/10. URL: www.imf.org.

2. Andrianova, S., Demetriades P., Shortland, A. (2009). Is Government Ownership of Banks Really Harmful to Growth? University of Leicester Working Paper No. 09/11.

3. Ata Can Bertay. Asli Demirgüç-Kunt. Harry Huizinga. Is lending by state banks more stable over the business cycle? [Online]. Available at http://www.voxeu.org/article/lending-state-banks-more-stableover-business-cycle.

4. Barth, J. R. Caprio, G. Levine, R. (2000). Banking Systems Around the Globe: Do Regulation and Ownership Affect Performance and Stability? World Bank Working Paper 2325. URL: http://econ.worldbank.org.

5. Barth, J. R. Caprio, G. Levine, R. (2004). Bank regulation and supervision: what works best? Journal of Financial Intermediation, 13(2), 205-248.

6. Beck, T., Crivelli, J. M., Summerhill, W. (2005). State bank transformation in Brazil Choices and consequences, Journal of Banking and Finance, 29.

7. Beck, T. R. Levine and N. Loayza (2000). Finance and the Sources of Growth. Journal of Financial Economics, 58(1-2), 261-300. 
8. Berger, A., Klapper, L. Martinez Peria, M. S., Zaidi, R. (2006). Bank Ownership Type and Banking Relationships. World Bank Policy Research Working Paper 3862.

9. Caprio, G., Honohan, P. (2001). Finance for growth: policy choices in a volatile world. World Bank policy research report. 1st ed. Oxford: Oxford University Press.

10. CEE Banking Sector Report Raiffeisen Research [Online]. Available at http://www.rb.cz/attachements/pdf/analyzy/banking.pdf.

11. China Banking Regulatory Commission 2010 Annual Report. [Online]. Available at http://www.cbrc.gov.cn/EngdocView.do?docID=20110419222D1DDDE39BE80AFFEB3FF789309200.

12. Das, Abhiman and Ghosh, Saibal (2007). Determinants of Credit Risk in Indian State-owned Banks: An Empirical Investigation. Economic Issues, 12(2), 48-66.

13. Demirguc-Kunt, A., Huizinga, H. (2000). Determinants of commercial bank interest margins and profitability: Some international evidence. World Bank Economic Review, 13, 379-408.

14. Demirguc-Kunt, A., Maksimovic, V. (1998). Law, finance and firm growth. Journal of Finance, 53, $2107-$ 2137.

15. Gershenkron, A. (1962). Economic Backwardness in Historical Perspective. Cambridge: Belknap Press of Harvard University Press.

16. Glushkova, E. A. (2009). Borders of the public sector in the banking system. Banking, 8, 34-37.

17. Helfert, E. (2003). Technique of financial analysis. 10 th ed. St. Petersburg: Peter, 640 p.

18. King, Robert G. and Levine, Ross (1993). Finance and Growth: Schumpeter Might Be Right. Quarterly Journal of Economics, 108(3), 717-737.

19. Kornai, Janos (1979). Resource-constrained vs. Demand-constrained Systems. Econometrica, 47, 801-819.

20. Korner T., Schnabel I. (2010). Public Ownership of Banks and Economic Growth The Role of Heterogeneity. Preprints of the Max Plancklnstitute for Research on Collective Goods. 2010/41. September 2010.

21. La Porta R., Lopez-de-Silanes F. (1999). The benefits of privatization: Evidence from Mexico. Quarterly Journal of Economics, 114, 1193-1242.

22. La Porta R., Lôpez-de-Silanes F., Shleifer A. (2002). Government ownership of banks. Journal of Finance, 57 (1). 265-301.

23. Levine, Ross and Zervos Sara (1998). Stock Markets, Banks and Economic Growth. American Economic Review, 88(3), 537-58.

24. Levy Yeyati E., Micco A., Panizza U. (2004). Should the Government Be in the Banking Business? The Role of State-Owned and Development Banks. Inter-American Development Bank Working Paper 517. URL: http://www.iadb.org/.

25. Lewis, W. A. (1955). The Theory of Economic Growth. London: Allen \& Unwin, $453 \mathrm{p}$.

26. Mutually assured existence. The Economist [Online]. Retrieved from http://www.economist.com/node/ 16078466?story_id=16078466.

27. Myrdal G. (1971). The Political Element in the Development of Economic Theory. L.: Routledge \& Kegan Paul - xvii. 248 p.

28. Rajan, Raghuram G. and Zingales, Luigi (1998). Financial Dependence and Growth. American Economic Review, 88(3), 559-86.

29. Shleifer A. (1998). State versus private ownership. Journal of Economic Perspectives, 12.

30. Shleifer A., Vishny R. (1994). Politicians and firms, Quarterly Journal of Economics, 109.

31. Worldwide statistics [electronic source] access mode - data.worldbank.org

32. Wurgler Jeffrey (2000). Financial markets and the allocation of capital. Journal of Financial Economics, $58(1-2), 187-214$.

33. Zuzana Fungácová \& Laura Solanko \& Laurent Weill (2010). Market power in the russian banking industry. Economie Internationale, 124, 127-146. 


\section{Appendix}

Table 1. Summary results of the study stabilization function of public banks in the economy

\begin{tabular}{|c|c|c|c|c|}
\hline \multirow[t]{2}{*}{ Variables and statistical characteristics } & \multicolumn{4}{|c|}{$\begin{array}{c}\begin{array}{c}\text { Coefficients of independent variables in regression equations in the model } \\
\text { of dependence of the volume of loans in the country's economy on the } \\
\text { respective independent variables }\end{array} \\
\end{array}$} \\
\hline & Equation 1 & Equation 2 & Equation 3 & Equation 4 \\
\hline Logarithm of loans & $\begin{array}{c}1,002 * * * \\
(0.000)\end{array}$ & $\begin{array}{c}0,998 * * * \\
(0.000)\end{array}$ & $\begin{array}{c}0,994 * * * \\
(0.000) \\
\end{array}$ & $\begin{array}{c}0,991 * * * \\
(0.000) \\
\end{array}$ \\
\hline GDP growth per capita & $\begin{array}{c}0.020^{* * * *} \\
(0.000)\end{array}$ & $\begin{array}{c}0.020^{* * * *} \\
(0.000)\end{array}$ & $\begin{array}{c}0.017 * * * \\
(0.000)\end{array}$ & $\begin{array}{c}0.017^{* * *} \\
(0.000)\end{array}$ \\
\hline $\begin{array}{l}\text { A fictitious variable that determines the participation of the state in the cap- } \\
\text { ital of banks (Fictitious change of state banks is equal to } 1 \text {, if the bank is in } \\
\text { state ownership with a controlling interest) }\end{array}$ & $\begin{array}{c}0.047^{* *} \\
(0.022)\end{array}$ & $\begin{array}{c}0.054^{* *} \\
(0.037)\end{array}$ & $\begin{array}{c}0.053 * * * \\
(0.006)\end{array}$ & $\begin{array}{c}0.059^{* * *} \\
(0.002)\end{array}$ \\
\hline $\begin{array}{l}\text { GDP growth rate per capita * A fictitious variable that determines the par- } \\
\text { ticipation of the state in the capital of banks }\end{array}$ & $\begin{array}{c}-0.013 * * * \\
(0.000)\end{array}$ & $\begin{array}{c}-0.014 * * * \\
(0.000) \\
\end{array}$ & $\begin{array}{c}-0.011^{* * *} \\
(0.000) \\
\end{array}$ & $\begin{array}{c}-0.011 * * * \\
(0.001) \\
\end{array}$ \\
\hline $\begin{array}{l}\text { Effectiveness of the government (the quality of public services index, the } \\
\text { quality of civil service and the degree of its independence from political } \\
\text { pressure, the quality of policy development and implementation, and the } \\
\text { credibility of such a government policy) }\end{array}$ & & & $\begin{array}{l}-0.050 \\
(0.120)\end{array}$ & $\begin{array}{l}-0.048 \\
(0.161)\end{array}$ \\
\hline $\begin{array}{l}\text { GDP growth per capita * Fictitious variable determining the state's partici- } \\
\text { pation in bank capital * Efficiency of government }\end{array}$ & & & $\begin{array}{c}-0.005 * * \\
(0.027)\end{array}$ & $\begin{array}{l}-0.004 \\
(0.105)\end{array}$ \\
\hline Assets (the logarithm of the total assets in the constants of $\$ 2,000$ ) & $\begin{array}{l}-0.007 \\
(0.508) \\
\end{array}$ & $\begin{array}{l}-0.003 \\
(0.806) \\
\end{array}$ & $\begin{array}{l}-0.001 \\
(0.947) \\
\end{array}$ & $\begin{array}{c}0.001 \\
(0.869)\end{array}$ \\
\hline Capital to Assets & $\begin{array}{c}0.069 \\
(0.350) \\
\end{array}$ & $\begin{array}{c}0.040 \\
(0.778) \\
\end{array}$ & $\begin{array}{l}-0.018 \\
(0.797) \\
\end{array}$ & $\begin{array}{c}-0.034 \\
(0.658) \\
\end{array}$ \\
\hline Loans to Assets & & $\begin{array}{l}-0.080 \\
(0.375) \\
\end{array}$ & & $\begin{array}{l}-0.055 \\
(0.115) \\
\end{array}$ \\
\hline Exclusivity (ratio of liquid assets to total assets) & & $\begin{array}{c}0.045 \\
(0.772)\end{array}$ & & $\begin{array}{c}0.018 \\
(0.681)\end{array}$ \\
\hline Deposits to liabilities & & $\begin{array}{c}0.041 \\
(0.453) \\
\end{array}$ & & $\begin{array}{c}0.025 \\
(0.278) \\
\end{array}$ \\
\hline $\begin{array}{l}\text { Cooperative banks (a fictitious variable equal to } 1 \text {, if the bank is co-opera- } \\
\text { tive, and } 0 \text { - otherwise) }\end{array}$ & & $\begin{array}{l}0.048^{* *} \\
(0.013)\end{array}$ & & $\begin{array}{c}0.053 * * * \\
(0.001)\end{array}$ \\
\hline $\begin{array}{l}\text { Mortgage banks (a fictitious variable equal to 1, if the bank is mortgage, } \\
\text { and } 0 \text { - otherwise) }\end{array}$ & & $\begin{array}{c}0.012 \\
(0.583)\end{array}$ & & $\begin{array}{c}0.013 \\
(0.545)\end{array}$ \\
\hline $\begin{array}{l}\text { Savings banks (fictitious variable equal to } 1 \text { if the bank is a savings, and } 0 \\
\text { - otherwise) }\end{array}$ & & $\begin{array}{c}0.026 \\
(0.232) \\
\end{array}$ & & $\begin{array}{c}0.010 \\
(0.497)\end{array}$ \\
\hline GDP per capita (in thousands of constants, $\$ 2,000$ at constant prices) & $\begin{array}{c}-0.001 * * \\
(0.022) \\
\end{array}$ & $\begin{array}{l}-0.001 \\
(0.369) \\
\end{array}$ & $\begin{array}{c}0.001 \\
(0.618)\end{array}$ & $\begin{array}{c}0.001 \\
(0.642) \\
\end{array}$ \\
\hline Inflation (the rate of change of GDP deflator) & $\begin{array}{c}-0.004 * * * \\
(0.000)\end{array}$ & $\begin{array}{c}-0.004 * * * \\
(0.010)\end{array}$ & $\begin{array}{c}-0.005^{* * * *} \\
(0.000) \\
\end{array}$ & $\begin{array}{c}-0.004 * * * \\
(0.000)\end{array}$ \\
\hline Number of observations & 6181 & 6081 & 5218 & 5132 \\
\hline Number of banks & 1633 & 1609 & 1506 & 1483 \\
\hline Number of tools & 272 & 278 & 352 & 358 \\
\hline AR test & 0.508 & 0.611 & 0.933 & 0.841 \\
\hline OIR is the p-significance test of Hansen & 0.200 & 0.269 & 0.818 & 0.847 \\
\hline
\end{tabular}

Notes: All regression equations are analyzed using a two-stage GMM estimation system with Windmeijer correction. The P-value for standard errors is shown in brackets. $*, * *, * * *$ denote significance by $10 \%, 5 \%$ and $1 \%$. 